九州大学学術情報リポジトリ

Kyushu University Institutional Repository

\title{
Cooling Improvement of the IT Rack by Layout Rearrangement of the A2 Class Data Center Room: A Simulation Study
}

Dyah Arum Wulandari

Department of Mechanical Engineering, Faculty of Engineering, Universitas Indonesia

Muhammad Akmal

Department of Mechanical Engineering, Faculty of Engineering, Universitas Indonesia

Gunawan, Yohanes

Department of Mechanical Engineering, Faculty of Engineering, Universitas Indonesia

Nasruddin

Department of Mechanical Engineering, Faculty of Engineering, Universitas Indonesia

https://doi.org/10.5109/4150468

出版情報：Evergreen. 7 (4)，pp.489-499，2020-12. 九州大学グリーンテクノロジー研究教育センター バージョン：

権利関係 : 


\title{
Cooling Improvement of the IT Rack by Layout Rearrangement of the A2 Class Data Center Room: A Simulation Study
}

\author{
Dyah Arum Wulandari ${ }^{1,2}$, Muhammad Akmal ${ }^{1}$, Yohanes Gunawan ${ }^{1,3}$ Nasruddin $\left.^{1, *}\right)$ \\ ${ }^{1}$ Department of Mechanical Engineering, Faculty of Engineering, Universitas Indonesia, Kampus Baru-Depok, \\ Jawa Barat, 16424 \\ ${ }^{2}$ Department of Mechanical Engineering Education, Faculty of Engineering, Universitas Negeri Jakarta, Jakarta \\ 13220, Indonesia
}

${ }^{3}$ Research and Development Center for Electricity, New, Renewable Energy and Energy Conservation Technology (P3tek KEBTKE), Ministry of Energy and Mineral Resources (KESDM) Republic Indonesia

${ }^{*}$ Author to whom correspondence should be addressed:

Email: nasruddin@eng.ui.ac.id

(Received May 2, 2020; Revised November 5, 2020; accepted November 5, 2020).

\begin{abstract}
Information technology (IT) devices that are capable of transferring large data fast will generate more heat discharged into the data center room (DCR). As a result, energy consumption to cool DCR becomes higher. This research aims to study the simulation of airflow and temperature as an indicator of the quality of rack cooling performance in the A2 Class Data Center, and to obtain a new rack layout recommendation that can distribute heat from IT devices to DCR optimally. Simulation was conducted with the help of ANSYS 16.2 software. The meshing sizes used were 645 nodes, 29.304 lines, 10.81 .976 hexahedral volumes, and 667.492 quadrilaterals. The solver used was pressure-based, while the sub-viscous setting used the $k-\varepsilon$ standard turbulence model. The validation of the simulation model was done by comparing the RH values and the temperature of the measurement results from DCR. The study result shows the performance for cooling DCR increased when the rack rearrangement in DCR space was implemented according to the layout of the results of the simulation. The indicator of the cooling performance improvement was the value of the RCI (Rack Cooling Index) which increased by $4.92 \%$ while the amount of SHI (Supply Heating Index) decreased by 0.047
\end{abstract}

Keywords: Cooling Performance, Data Center Room, IT equipment, Rack Cooling Index, Supply Heating Index

\section{Introduction}

Almost all companies, governments, banks, public facilities, and universities have servers stored in a data center room $^{1)}$ and application supporting computer systems. Since both are required to work continuously, data center rooms must have high data security and maintenance standards and must be equipped with room cooling systems that meet the American Society of Heating, Refrigerating and Air-Conditioning Engineers (ASHRAE) standards's). Table 1 and Figure 1 show the standard thermal area in several data center categories referring to ASHRAE TC 9.92).

The energy requirements for supplying power to data centers are substantial. For example, in the United States, $2 \%$ of the total available energy is used to supply power to data centers ${ }^{3-6}$. The problem, arises when the demand that the server can transfer and store data quickly will increase the temperature of the electronic devices inside the server and the cooling load ${ }^{7,8)}$. The portion of energy consumption for cooling systems in buildings reaches $38 \%$, but more than half of the cooling data centers run inefficiently ${ }^{9-12)}$.

To reduce energy consumption for cooling the data center room, fluid flow in the data center needs to be optimized, by following these 4 (four) energy conservation measures ${ }^{13)}$ : 1) unnecessary computer room air conditioning (CRAC) can be removed; 2) The air temperature in the CRACs is increased; 3) Cold aisle retainer added; and 4) Applying a fresh air cooler. Padmanabhan et al. ${ }^{14)}$, in their research, concluded that algorithms for a collection of periodic tasks could reduce the energy consumption of embedded devices by $20-$ $40 \%$. Peng et al. ${ }^{3)}$ also studied the effects of various 
variations in heat performance on the workload of the air conditioner and produced an effective method for measuring energy savings. Oró et al. ${ }^{4}$ used TRNSYS software to analyze the air system in the data center and observed regular air circulation and heat-producing points. Meanwhile dynamic models were used to analyze how to reduce waste in air circulation. Rong et al. ${ }^{15)}$ reviewed the energy-saving technology available in the data center and produced an energy-saving trend in the data center going forward.

In addition to regulating the performance system of supercomputers in the data center, increasing efficiency in the data center can also be done by modifying building devices. Pillai et al. ${ }^{14)}$ investigated and analyzed the performance metrics of cooling systems and energy consumption. However, the research did not use a heat recovery system in the data center. Additionally, exhaust heat from the cooling system in the data center room could be collected with additional condensers. Zhang et al. ${ }^{15)}$ analyzed the heat recovery system from an internet-based data center on an air conditioner and developed an hourly energy consumption model of a heat recovery system. Lu et al. ${ }^{16)}$ suggested that a central air circulation system using a roof ventilation layer and a phase change material (PCM) unit to control heat loads and peak loads.

Researchers have also found that natural energy can be used to reduce indoor energy consumption. Siriwardana et al. ${ }^{17)}$ initiated a model of bottom-up energy system optimization to reduce environmental impacts and increase savings. Their study combined the exploitation of primary energy sources, power and heat, emissions, and the user sector. In addition the model has also been modeled in building areas. Rasmussen ${ }^{18)}$, stated that air return is generally located at the top of the Precision AC unit so that the air is cooled directly on the Precision AC unit. For the height of the position of the air return itself, it can be modified through the design of the server room. Thermal conditions in the data center are dynamic due to many parameters; hence, they cannot be captured through steady-state analysis alone ${ }^{19)}$. The first transient numerical analysis was performed by Beitelmal and Patel studying the impact of CRAC failure on the temperature variations in the data center ${ }^{20)}$. A qualitative assessment study has been done by Schmidt and Iyengar ${ }^{21)}$ showing that the rising floor air supply in the data center room provided a cooler rack entry temperature. Herrlin et al. have conducted a CFD (computational fluid dynamics) simulation using various heat density in the data center and provided a complete picture of the thermal environment for electronic equipment ${ }^{22)}$.

Since the temperature and airflow in DCR are essential safety components to be considered ${ }^{23)}$, this study aims to get an overview of temperature and airflow distribution in DCR with the help of CFD software. The data centers studied in this research are included in the
A2 category, as seen in Table 2. This study would produce the new rack layout recommendations in Class A2 Data Centers that can distribute heat optimally. The indicators of the cooling performance increase used in this research include RCI (rack cooling index), SHI (supply heating index), and RHI (return heating index). The recommendation to improve cooling performance by re-arranging rack position in the A2 Class data center room with the help of CFD software has never been conducted earlier.

Table 1. Data center room environment standards by ASHRAE TC $9.9^{2)}$

\begin{tabular}{|c|c|c|c|c|c|c|c|c|c|c|}
\hline \multirow[b]{3}{*}{ 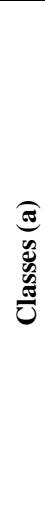 } & \multicolumn{10}{|c|}{ Equipment Enviromental Spesifications } \\
\hline & \multicolumn{6}{|c|}{$\begin{array}{l}\text { Product Operations } \\
\text { (b) (c) }\end{array}$} & \multicolumn{4}{|c|}{$\begin{array}{c}\text { Product Power } \\
\text { Off (c) (d) }\end{array}$} \\
\hline & 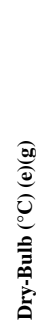 & 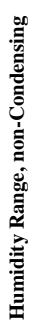 & $\overparen{\cong}$ & 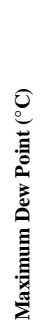 & 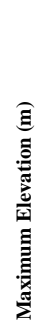 & 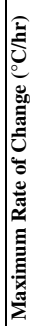 & 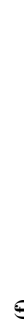 & 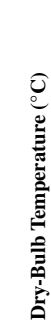 & 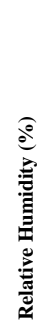 & $\begin{array}{l}0 \\
0 \\
0 \\
.0 \\
0\end{array}$ \\
\hline
\end{tabular}

(Applies to all A classes; individual data centers can choose to expand this range based upon the analysis described in this document)

\begin{tabular}{|c|c|c|c|c|c|c|c|c|}
\hline $\begin{array}{l}\text { A1 } \\
\text { to } \\
\text { A4 }\end{array}$ & $\begin{array}{l}18 \\
\text { to } \\
27\end{array}$ & $\begin{array}{c}5.5^{\circ} \mathrm{C} \\
\text { DP to } \\
60 \% \mathrm{RH} \\
\text { and } 15^{\circ} \mathrm{C} \\
\text { DP }\end{array}$ & & & & & & \\
\hline \multicolumn{9}{|c|}{ Allowable } \\
\hline A1 & $\begin{array}{l}15 \\
\text { to } \\
32\end{array}$ & $\begin{array}{l}20 \% \text { to } \\
80 \% \mathrm{RH}\end{array}$ & 17 & 3050 & $\begin{array}{c}5 / 2 \\
0\end{array}$ & $\begin{array}{l}5 \\
\text { to } \\
45\end{array}$ & $\begin{array}{l}8 \\
\text { to } \\
80\end{array}$ & 27 \\
\hline A2 & $\begin{array}{l}10 \\
\text { to } \\
35\end{array}$ & $\begin{array}{l}20 \% \text { to } \\
80 \% \mathrm{RH}\end{array}$ & 21 & 3050 & $\begin{array}{c}5 / 2 \\
0\end{array}$ & $\begin{array}{l}5 \\
\text { to } \\
45\end{array}$ & $\begin{array}{l}8 \\
\text { to } \\
80\end{array}$ & 27 \\
\hline A3 & $\begin{array}{l}5 \text { to } \\
40\end{array}$ & $\begin{array}{c}-12^{\circ} \mathrm{C} \\
\text { DP \& 8\% } \\
\text { RH to } \\
85 \% \text { RH }\end{array}$ & 24 & 3050 & $\begin{array}{c}5 / 2 \\
0\end{array}$ & $\begin{array}{l}5 \\
\text { to } \\
45\end{array}$ & $\begin{array}{l}8 \\
\text { to } \\
80\end{array}$ & 27 \\
\hline A4 & $\begin{array}{l}5 \text { to } \\
45\end{array}$ & $\begin{array}{c}-12^{\circ} \mathrm{C} \\
\text { DP \& 8\% }\end{array}$ & 24 & 3050 & $5 / 2$ & $\begin{array}{l}5 \\
\text { to } \\
45\end{array}$ & $\begin{array}{l}8 \\
\text { to } \\
80\end{array}$ & 27 \\
\hline
\end{tabular}




\begin{tabular}{|c|c|c|c|c|c|c|c|c|}
\hline & & $\begin{array}{c}\text { RH to } \\
90 \% \mathrm{RH}\end{array}$ & & & & & & \\
\hline & 5 to & $8 \%$ to & 28 & 3050 & NA & $\begin{array}{c}5 \\
\text { to } \\
45\end{array}$ & $\begin{array}{c}8 \\
\text { to } \\
80\end{array}$ & 27 \\
\hline & 35 & $80 \% \mathrm{RH}$ & & & & & \\
\hline C & 4 to & $8 \%$ to & 28 & 3050 & & $\begin{array}{c}5 \\
\text { to }\end{array}$ & $\begin{array}{c}8 \\
\text { to }\end{array}$ & 27 \\
& $40 \% \mathrm{RH}$ & & & NA & $\begin{array}{c}27 \\
80\end{array}$ & \\
\hline
\end{tabular}

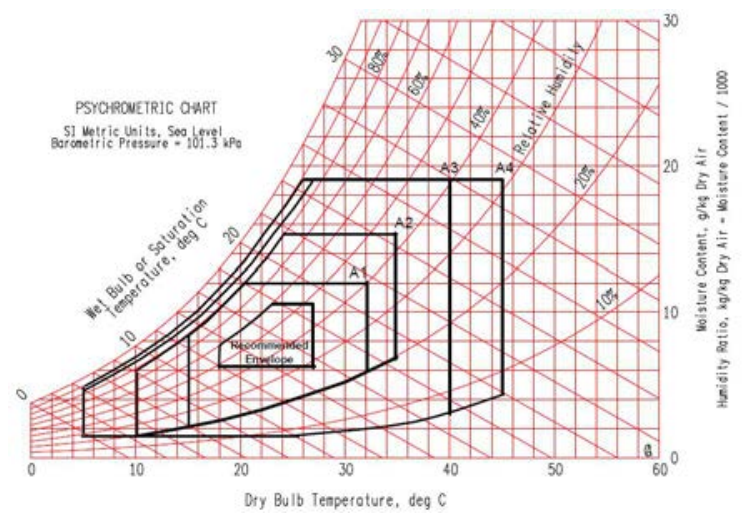

Fig. 1: Psychrometric chart and boundaries of each category of data centers room ${ }^{2)}$

Table 2. Classification of data center room by ASHRAE in

\begin{tabular}{|c|c|c|c|c|}
\hline \multicolumn{5}{|c|}{2008 and $2011^{2)}$} \\
\hline $\begin{array}{c}2008 \\
\text { Clas } \\
\text { ses } \\
\end{array}$ & $\begin{array}{c}2011 \\
\text { Clas } \\
\text { ses }\end{array}$ & $\begin{array}{c}\text { Applica } \\
\text { tions }\end{array}$ & $\begin{array}{l}\text { Information } \\
\text { Technology } \\
\text { Equipment }\end{array}$ & $\begin{array}{c}\text { Environmental } \\
\text { Controls }\end{array}$ \\
\hline 1 & A1 & 0.2 & $\begin{array}{l}\text { Enterprise } \\
\text { Servers, } \\
\text { Storage } \\
\text { Products }\end{array}$ & $\begin{array}{c}\text { Tightly } \\
\text { Controlled }\end{array}$ \\
\hline 2 & $\begin{array}{l}\text { A2 } \\
\text { A3 } \\
\text { A4 }\end{array}$ & $\begin{array}{l}\text { Data } \\
\text { Center }\end{array}$ & $\begin{array}{c}\text { Volume } \\
\text { Servers, } \\
\text { Storage } \\
\text { Products, } \\
\text { Personal } \\
\text { Computers, } \\
\text { Workstations }\end{array}$ & $\begin{array}{l}\text { Some Control, } \\
\text { Use of Free } \\
\text { Cooling } \\
\text { Techniques } \\
\text { When } \\
\text { Allowable } \\
\text { Some Control, } \\
\text { Near Full-Time } \\
\text { Usage of } \\
\text { Free-Cooling } \\
\text { Techniques } \\
\end{array}$ \\
\hline 3 & B & $\begin{array}{c}\text { Office } \\
\text { Home, } \\
\text { Transpo } \\
\text { rtable } \\
\text { Environ } \\
\text { ment, } \\
\text { etc. }\end{array}$ & $\begin{array}{c}\text { Personal } \\
\text { Computers, } \\
\text { Workstations, } \\
\text { Laptops, and } \\
\text { Printers }\end{array}$ & $\begin{array}{l}\text { Minimal } \\
\text { Control }\end{array}$ \\
\hline 4 & C & $\begin{array}{l}\text { Point-of } \\
\text {-sale } \\
\text { Industri }\end{array}$ & $\begin{array}{c}2 \\
\text { Point-of-Sale } \\
\text { Equipment, }\end{array}$ & No Control \\
\hline
\end{tabular}

\begin{tabular}{|l|l|c|c|l|}
\hline & $\begin{array}{c}\text { al, } \\
\text { Factory, } \\
\text { etc. }\end{array}$ & $\begin{array}{c}\text { Ruggedized } \\
\text { Controllers, or } \\
\text { Computers } \\
\text { and PDAs }\end{array}$ & \\
\hline
\end{tabular}

\section{Methodology}

\subsection{Rack Cooling Performance}

The performance of the server rack is often described with the temperature of the data rack entry. The commonly used efficiency index from the server rack is rack cooling index (RCI). RCI is the recommended ratio of excess air temperature into the server rack to cool the total excess temperature allowed. In general, RCI is described with the formula:

$$
\mathrm{RCI}=\left[1-\frac{\sum_{\mathrm{x}=1}^{\mathrm{n}}\left(\mathrm{T}_{\mathrm{x}}-\mathrm{T}_{\text {max }- \text { rec }}\right)_{\mathrm{T}_{\mathrm{x}}>\mathrm{T}_{\text {max }-\mathrm{rec}}}}{\left(\mathrm{T}_{\text {max }- \text { all }}-\mathrm{T}_{\text {max }-\mathrm{rec}}\right) \mathrm{n}}\right] \mathrm{x} 100 \%
$$

Where $T_{x}$ is the temperature of the air entering the rack when it exceeds the recommended temperature. $\mathrm{T}_{\text {max-rec }}$ is the maximum recommended temperature $\left(27^{\circ} \mathrm{C}\right.$ in this study), while $\mathrm{T}_{\text {max-all }}$ is the maximum allowable temperature $\left(35^{\circ} \mathrm{C}\right.$ in this study). As an illustration, the following are the positions of each temperature involved in RCI calculations.

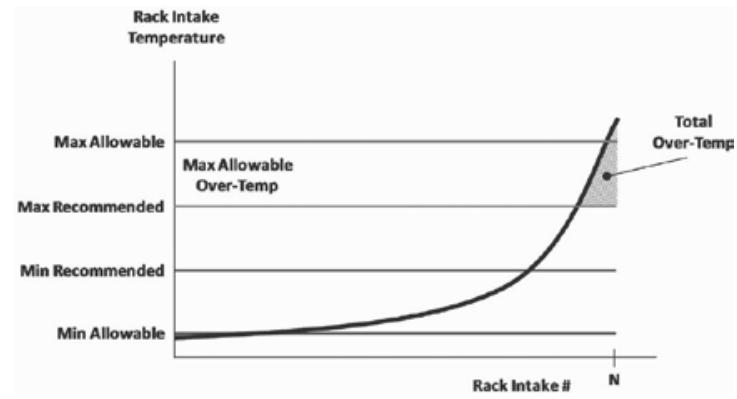

Fig. 2: Definition of various temperatures in RCI calculations according to ASHRAE TC $9.9(2011)^{2)}$

In addition to RCI, the important parameter in the analysis is cooling efficiency. Cho et al. ${ }^{24)}$ analyzed the impact of the cold aisle and hot aisle separation on cooling efficiency, presenting alternatives to air distribution systems that are generally applied in the data center, and reviewing air temperature and speed distribution of each system. Efficiency evaluation for each air distribution system was carried out in six alternative cases based on the method of supplying air supply from AC and return air. From the average temperature distribution, the local supply distribution/raised-floor type air/local return infrastructure systems were verified as the most efficient air distribution method when a little air circulation at the top of the server could be effectively avoided. Air flow performance and cooling from the data center have been seen in the performance metric setup. SHI (supply heat index) is a function of the rack inlet and outlet 
temperature. SHI which was firstly discovered by Sharma et al. $^{25)}$ indicated that the ratio of the heat obtained by air in the cold aisle before entering the heat source on the rack caused by the hot air leaving the rack. The numbers obtained in the RHI parameter indicate effective heat dissipation from the data center. The existence of dimensionless parameters allows this formula to be scaled for systems of any dimension. This equation is defined as:

$$
\begin{aligned}
& \mathrm{SHI}=\left(\frac{\delta \mathrm{Q}}{\mathrm{Q}+\delta \mathrm{Q}}\right) \\
& \mathrm{RHI}=\left(\frac{\mathrm{Q}}{\mathrm{Q}+\delta \mathrm{Q}}\right) \\
& \mathrm{SHI}+\mathrm{RHI}=1
\end{aligned}
$$

Based on the formula, $\delta \mathrm{Q}$ is the enthalpy change / rise due to the heat mixed into the cold air from the AC supply, while $\mathrm{Q}$ is the total enthalpy change that occurs in the rack.

\subsection{Research Stage}

In conducting this research, the data retrieval until final appearance can be seen in Figure 3 Flowchart of Research Stages.

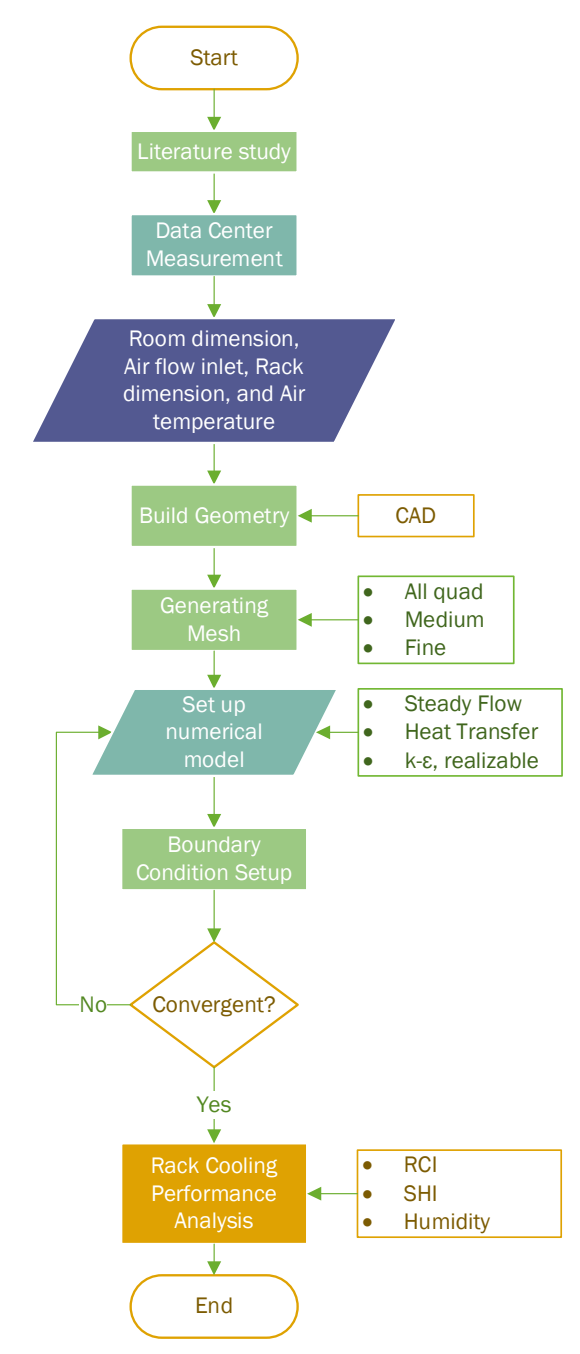

Fig. 3: Flowchart of research stages

Drawing models were simulated with actual designs located on site using CAD software and model simplification using SpaceClaim in ANSYS. Figure 4 illustrated the server space being tested:

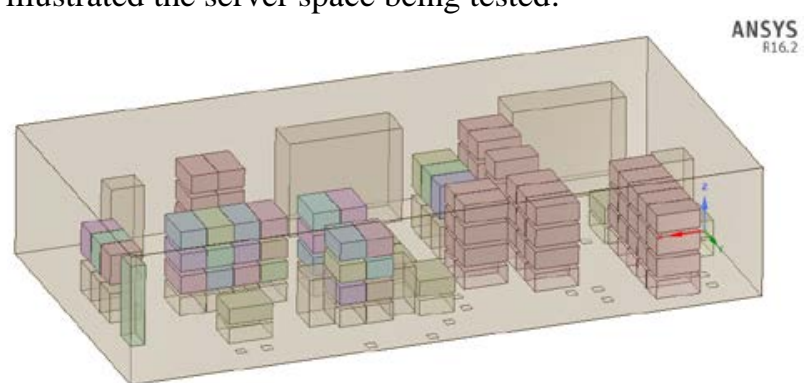

Fig. 4: Simplified model drawing on SpaceClaim Application

Meshing is the process of dividing a robust model into smaller elements, where the lower of the parts will be better; thus, boundary conditions and applicable parameters can be applied to the meshing results. The quality and quantity of mesh used greatly influences the simulation completion process. Meshing used in this 
simulation was discretized into 645 nodes, 29,304 lines, 10,081,976 hexahedral volumes, and 667,492 quadrilaterals. This mesh was applied in the whole surfaces of the model including volumetric mesh for the airflow simulation

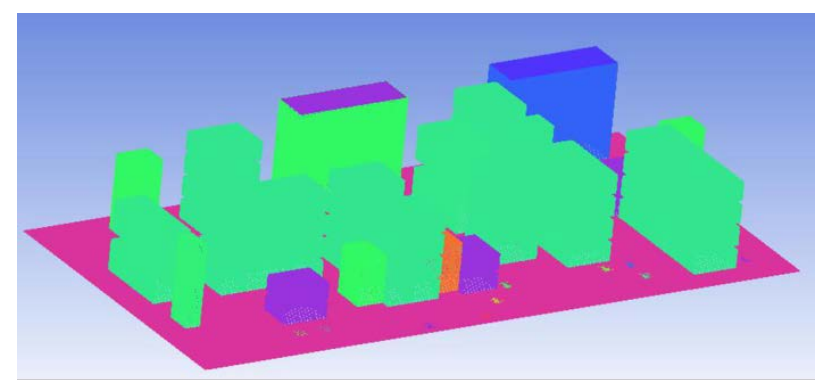

(a)

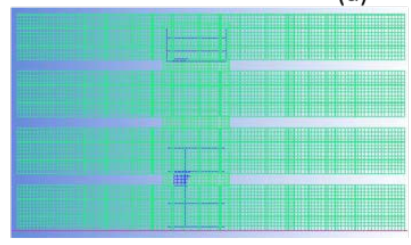

(b)

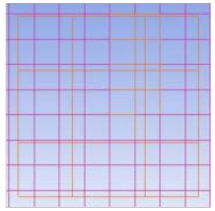

(c)
Fig. 5: Mesh results on: (a) isometric view of server room; (b) server rack; and (c) air inlets

After the meshing had been made, we made determination of boundary condition. For an inlet fluid in the form of air, which is incompressible fluid, the boundary condition was decided to be velocity inlet. Based on the measurement from the actual DCR, the mean inlet air velocity was $2.3 \mathrm{~m} / \mathrm{s}$ with air temperature of $16^{\circ} \mathrm{C}$. The PAC outlet and standing AC were determined as outflows. Whereas boundary condition for server racks, roofs, walls and floors was wall.

In the final stage of the simulation, data was obtained qualitatively both in terms of contours, vectors of temperature, heat transfer, and flow velocity. Furthermore, quantitative data were reviewed used as a reference for analyzing rack cooling performance both in theory and simulation. The data displayed was on the $\mathrm{X}$ $(\mathrm{x} / \mathrm{y})$ axis, the $\mathrm{Z}$ axis $(\mathrm{z} / \mathrm{x})$, and the $\mathrm{Y}$ axis $(\mathrm{y} / \mathrm{z})$. Then, the calculations of server rack cooling performance were in the form of RCI, SHI, RHI, RH distribution, and recommendation of evaluation in the data center room layout.

The DCR layout of this research is shown in Figure 6. The data that we used in this simulation are:

- Room dimension: 13.68 m x 7.2 m x 3 m

- Perforated tile area: $0.25 \mathrm{~m}$ x $0.25 \mathrm{~m}$

- PAC Outlet dimension: $1.2 \mathrm{~m}$ x $0.4 \mathrm{~m}$

- Rack dimension: $0.6 \mathrm{~m}$ x 0,8 m x 2,3 m

- Board dimension: $0.6 \mathrm{~m}$ x 0,8 m x 0,3 m

- Number of racks: 23 units for main rack and 10 units for smaller rack

- Inlet temperature: $16-17^{\circ} \mathrm{C}$

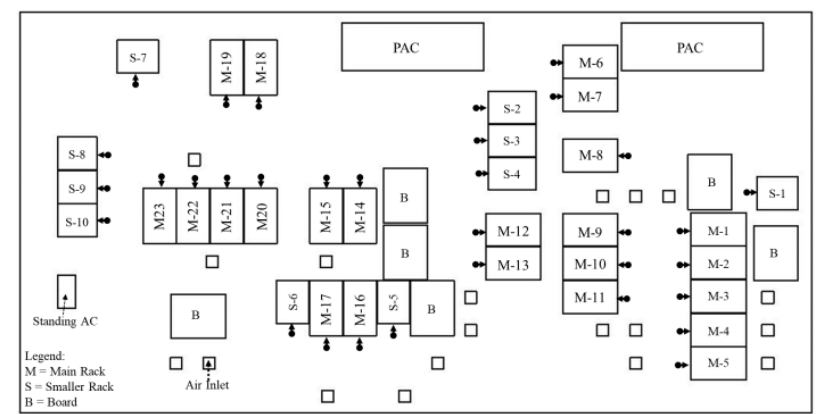

Fig. 6: The existing layout of data center room that studied in this research

\section{Result and Disccusion}

This section discusses the results of numerical simulations using ANSYS 16.2 CFD software by displaying fluid flow (air) in the room of the tested data center. This CFD simulation is described in the form of 3 dimensions so that air and heat flow can be seen in the $\mathrm{x}$, $\mathrm{y}$, and $\mathrm{z}$ axes. Moving heat in the room is described in the form of free convection, then seen also the distribution of air velocity, air temperature is also described in the Fluent software - CFD Post. Layout (placement) server rack, air inlet, PAC unit, and AC standing are described according to the original conditions in the field. The iteration was carried out after the determination of the simulation model and boundary conditions were carried out to reach the convergence value.
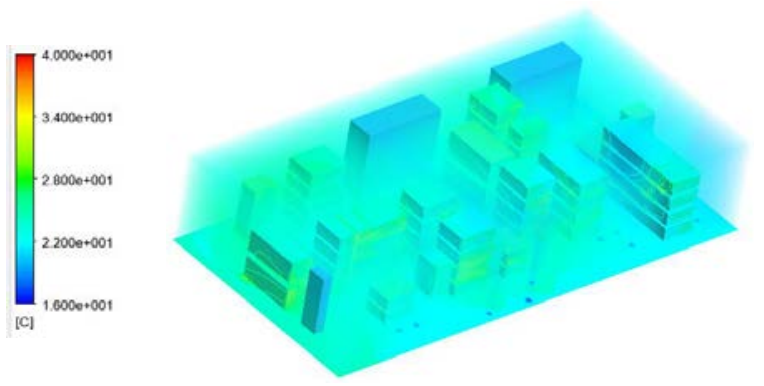

Fig. 7: Volume of temperature distribution on an isometric view

The temperature difference in the air will cause air flow. In this case, the high-density air coming out of the air inlet on the floor will move to the heat source which is the air around the rack where it has a higher temperature. Hot air from the rack has a lower density than the air coming out of the air inlet, so that heat transfer occurs between the hot air around the rack and cold air from the air inlet. This heat transfer can be referred to as natural convection (free convection). Then the fan inside the air conditioner unit will draw air from the room to be cooled again. This is what causes the process of taking heat from inside the room and results in the air in the room. 


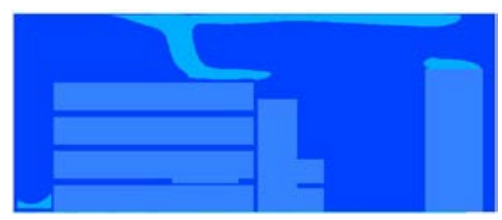

(a)

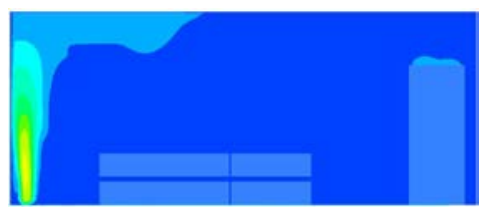

(b)

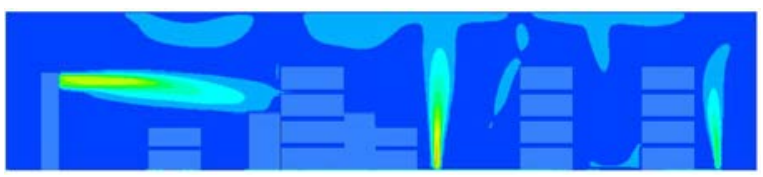

(c)

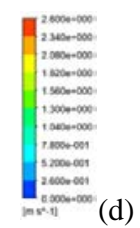

Fig. 8: Velocity contour on plane: (a) xy $1.6 \mathrm{~m}$, (b) xy $7.3 \mathrm{~m}$, (c) yz $1.5 \mathrm{~m}$, (d) acceleration profile of simulation.

It can be seen that the isometric image of the temperature volume of the data center room was tested as seen in Figure 7. It shows that the location of the PAC tends to be on the right side of the room; however on the left side of the room a standing floor type air conditioner unit has been added as an additional cooler. The air of the data center room based on the simulation results looks to have an average temperature of $21-22^{\circ} \mathrm{C}$, this has met the ASHRAE recommended standard, i.e. $18-27^{\circ} \mathrm{C}$. Then, the data center room is given a piece image to see the distribution of air temperature, the temperature on the rack surface, and air flow. Therefore, the cutout surface plane is placed parallel to the PAC unit, AC standing, and rack. This is done so that the air flow characteristics from the perforated tile to the AC unit can be properly described based on the measurement.

Figure 8 shows that there are many regions in the dark blue region, which is the low airspeed area, i.e. below 0.4 $\mathrm{m} / \mathrm{s}$. The highest air speed is only in the area around the air inlet of the AC at high speed, i.e. $2.6 \mathrm{~m} / \mathrm{s}$, while the PAC outlet is $0.5 \mathrm{~m} / \mathrm{s}$. That results in less optimal heat transfer from the rack due to cold air directly touching the roof of the room.

Figure 8 (a) shows that the flow of temperature when leaving the rack is $23-26^{\circ} \mathrm{C}$, where it is in accordance with the maximum standard of ASHRAE recommendations of $27^{\circ} \mathrm{C}$, while the total temperature of indoor air is $20-22^{\circ} \mathrm{C}$. In Figure $8(\mathrm{~b})$, the hot air temperature flow from the rack is $23-26^{\circ} \mathrm{C}$. Then the heat is focused on the rack outlet then air towards the PAC outlet. Meanwhile, Figure 8(c) shows region of hot air temperature is focused on the area around the rack and collected under the AC standing, then the temperature of the hot air around the rack is visible at 23 $-25^{\circ} \mathrm{C}$.

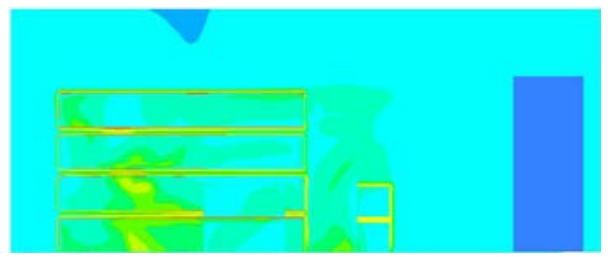

(a)

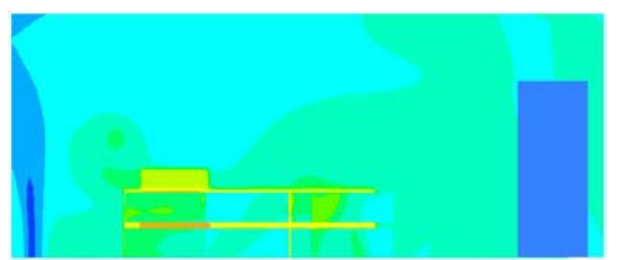

(b)

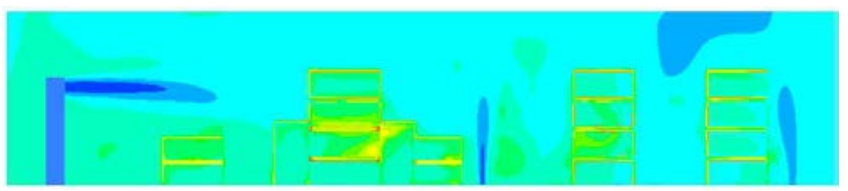

(c)

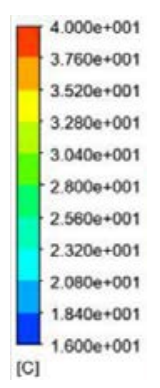

(d)

Fig. 9: Temperature contour on plane: (a) xy $1.6 \mathrm{~m}$, (b) xy $7.6 \mathrm{~m}$, (c) yz $1.5 \mathrm{~m}$, (d) temperature profile of simulation

\subsection{Relative Humidity}

When measurements were made on the server room, the temperature and $\mathrm{RH}$ room were $19.8^{\circ} \mathrm{C}$ and $59 \%$, respectively. Thus, using the psychrometric chart is obtained by absolute humidity of $10.083 \mathrm{~g} / \mathrm{m}^{3}$ air assuming atmospheric pressure is 101.325 Pascal. This absolute humidity is the content of saturated water contained in the air. The absolute humidity in this study was used to find the distribution of $\mathrm{RH}$ in the server room. It is assumed that the absolute humidity in the data center room does not change because the door of the room is always closed and the computer equipment in it does not produce additional moisture. Thus, there will be 
correlation between RH to temperature variations in the room. Here is a graph of the correlation between temperature (dry bulb) and RH in the server room tested:

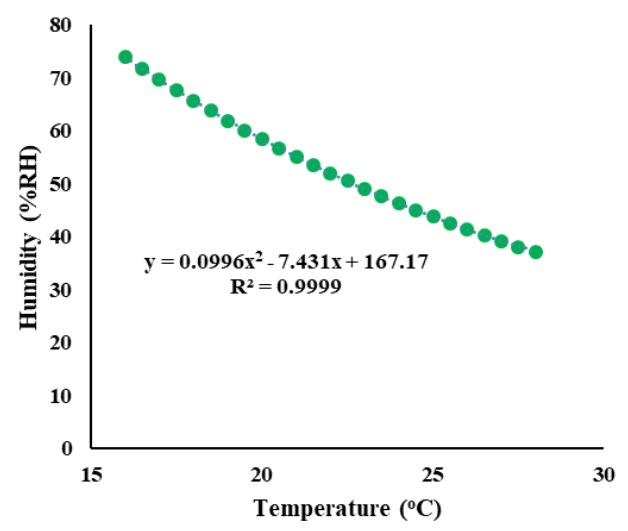

Fig. 10: Correlation between air temperature and relative humidity in studied data center room

Figure 10 shows a correlation between relative humidity to temperature variation. This graph is used to find the $\mathrm{RH}$ value in a data center room using the curve fitting method. Based on this picture, the second order polynomial equation is $\mathrm{y}=0.0996 \mathrm{x} 2-7.431 \mathrm{x}+167.17$ where $\mathrm{x}$ is the temperature of a point in the room, while $\mathrm{y}$ is relative humidity. Then the equation is used to find $\mathrm{RH}$ in front of each rack.
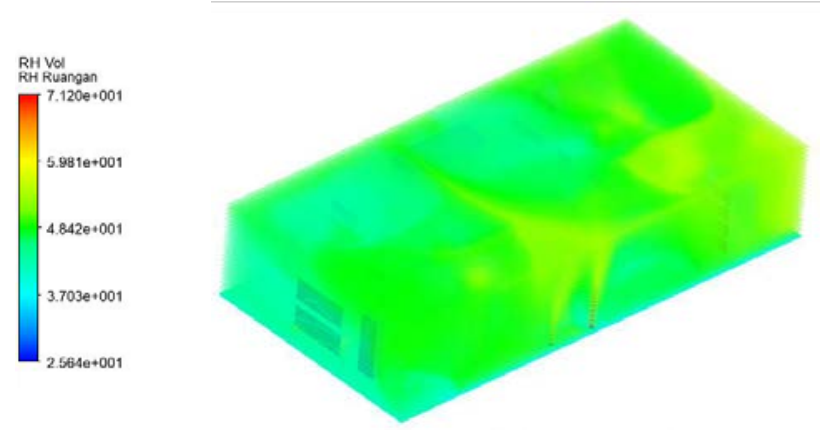

Fig. 11: Relative humidity distribution on studied data center room

The measurement point in Figure 11 was taken right in front of the server rack with four height variations, namely $0.4,0.8,1.2$, and $1.6 \mathrm{~m}$. This point of measurement aims to determine the distribution of $\mathrm{RH}$ in front of the rack. The measurement position of the $\mathrm{RH}$, can be seen in Figure 12.

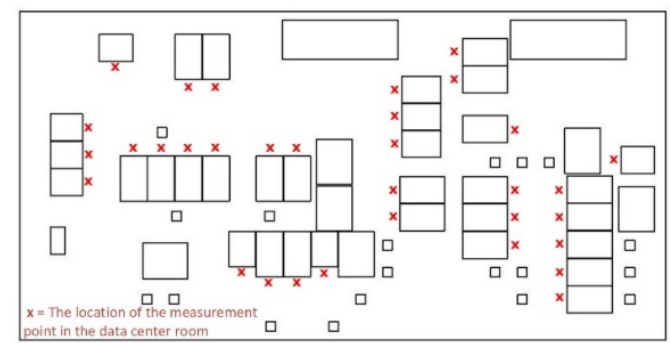

Fig. 12: The location of the measurement point in the data center room
The RH standard recommended by ASHRAE must not exceed $60 \%$. It aims to prevent condensation on electronic equipment on the server which results in an electric surge. It is also seen that the average $\mathrm{RH}$ range shown is equal to $49-53 \%$ where it includes good enough and there is no $\mathrm{RH}$ in front of the rack that exceeds ASHRAE's recommended standard of $60 \%$.

\subsection{Rack Cooling Index}

One indicator to see the cooling performance of a server rack is rack cooling index. The rack cooling index is the ratio between the intake temperatures that exceeds the recommended standard, i.e. $27^{\circ} \mathrm{C}$ with the range is between the permissible and recommended temperature, i.e. $35^{\circ} \mathrm{C}$. The following are the results and categories of RCI calculation on the server rack.

Table 3. RCI value category in the data center according to ASHRAE TC 9.92011.

\begin{tabular}{|c|c|}
\hline Rating & RCI(\%) \\
\hline Ideal & 100 \\
\hline Good & $\geq 96$ \\
\hline Acceptable & $91-95$ \\
\hline Poor & $\leq 90$ \\
\hline
\end{tabular}

Figure 13, shows that some racks in the initial layout are still below the minimum standard of the acceptable category, i.e. $91 \%$. The numbers of server racks that are still below the standard are 6 racks out of the 23 main racks available. In average, the RCI value is measured at $90.83 \%$, which is also below the acceptable standard. Then when it is mapped, the location of the various RCI values for each rack can be seen in Figure 14.

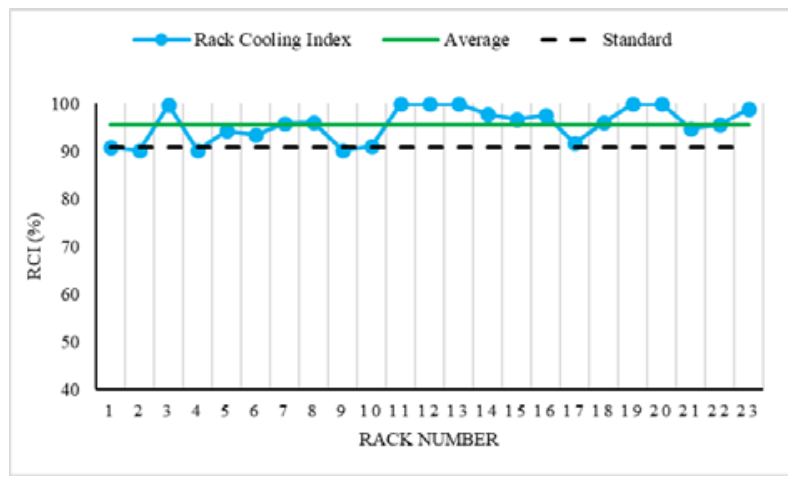

Fig. 13: RCI value on each rack

The red area number 1 in Figure 14 shows that the RCI value is below the $91 \%$ standard, as can be seen in Table 3. This is related to the number 1 area which is the left part of the room located far from the AC inlet diffuser, so that the rack cannot receive cold air supply properly. While the red area number 2 shows that the racks are located quite close even though in that area there is only one diffuser, in this case the racks will heat 
each other. Therefore, the RCI value becomes low seen on the left and right racks adjacent to the other racks only with one diffuser. Then in red number 3 , you can see the RCI value on the rack looks slightly lower than the rack next to it because it is blocked by a rack containing a PC. Meanwhile, area number 4 is the same as area number 3 where the racks gather in an area without any AC diffuser.

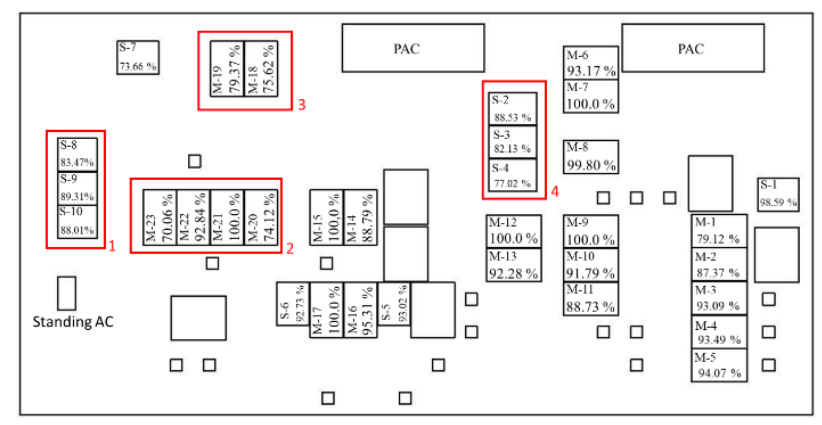

Fig. 14: The map of RCI value on each rack

\subsection{Supply Heat Index and Return Heat Index}

Supply heat index is an indication of the heat from the rack mixed in the flow of air supply from the perforated tile, while the return of heat index is the amount of heat that enters / is sucked into the AC. The total sum of SHI and RHI is 1 which is the total heat produced by the rack. Following are the calculation results of SHI and RHI.

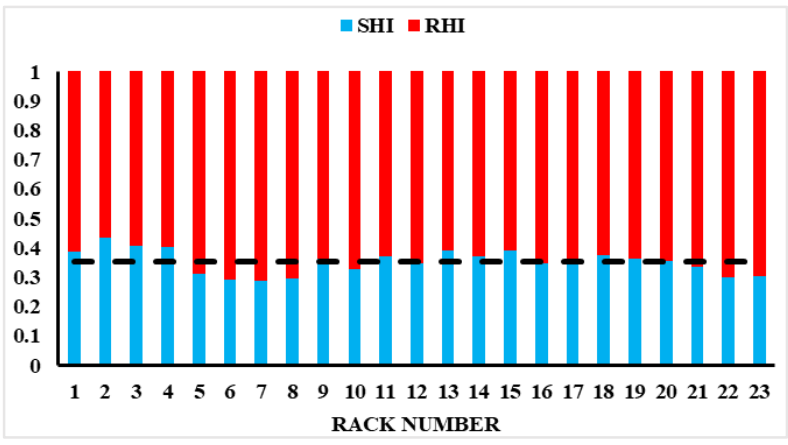

Fig. 15: SHI and RHI on the main racks

Figure 15 shows the average SHI on the main rack is 0.353. This means that there is $35.3 \%$ heat from the rack mixed in the supply air flow. There is no SHI category that can be said to be good, but in theory, ideally the SHI should be zero which indicates that there is no heat mixed into the flow of cold air.

\subsection{Evaluation on Rack Layout in Data Center}

One important factor of a data center room in maintaining the effectiveness of cooling performance is the division of zones of cold aisle and hot aisle. The two zones are intended to prevent heating between server racks and cold-temperature air will directly contact the rack, so that cooling is more effective. Cold aisle is a zone where cold air from perforated tiles collects and flow as convection to heat source, i.e. rack servers. While the hot aisle is a higher temperature zone where used air cools the racks together and flows to the PAC unit.

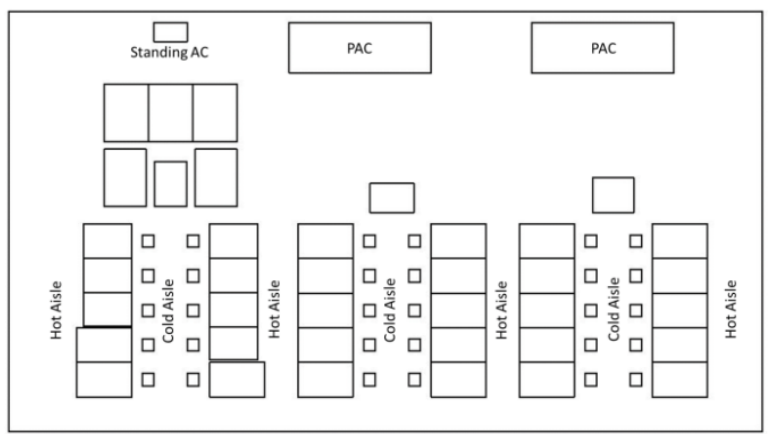

Fig. 16: The recommended rack layout in studied data center room

Figure 16 shows the recommended rack layout considers the presence of hot aisle and cold aisle zones, so that low temperature air from perforated tile will be more effective to cooling the racks. To see the effectiveness of cooling performance, it is necessary to do a simulation again using the recommended layout. Then the simulation results are compared between the initial layout and the recommended layout. The following are the simulation results from the rack layout recommended in this study.

Figure 17 shows the simulation results in the recommended rack layout. Visible distribution of air temperature is quite even with a range of $20-23^{\circ} \mathrm{C}$. The rack temperature range is also seen at $23-28^{\circ} \mathrm{C}$. The figure shows the flow of heat from the rack to the PAC outlet with a flow of air temperature of $24^{\circ} \mathrm{C}$. This figure also shows the flow of cold air from the AC.

Based on the simulation results, it is also necessary to calculate the cooling performance in the form of RCI, SHI, and RHI. Then the results of these calculations were compared with the initial conditions to see the effect of replacing the heat source layout of the data center room. The following are the results of calculation of performance compared to the initial conditions.

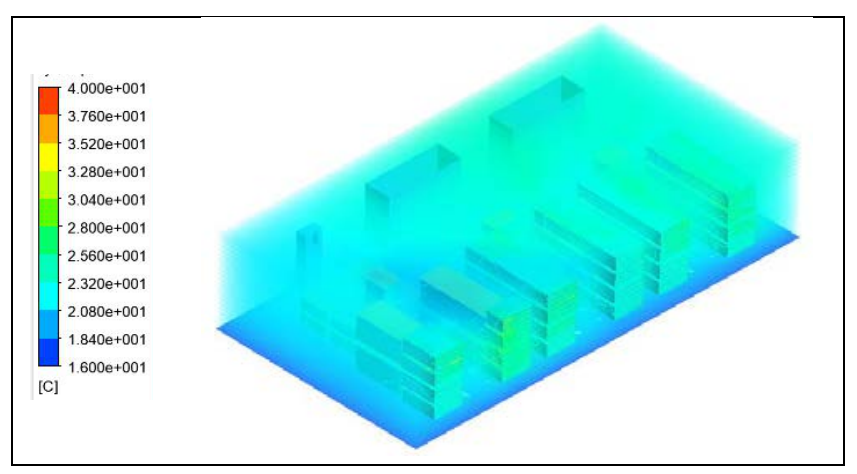

Fig. 17: Temperature distribution on an isometric view

Figure 18 shows that there were 6 main rack units in 
the initial layout which were still below the acceptable standard. While in the new layout, only 4 main racks were below the standard. In average, as seen in Figure 17, the RCI in old layout value is found to be $90.83 \%$, while the new layout is $95.75 \%$ which is in accordance with the standard. In addition to RCI, SHI is one of the parameters compared to seeing the heat from the rack mixed with cold air flow from the perforated tile. The following are the results of a comparison between the initial SHI layout and the new layout.

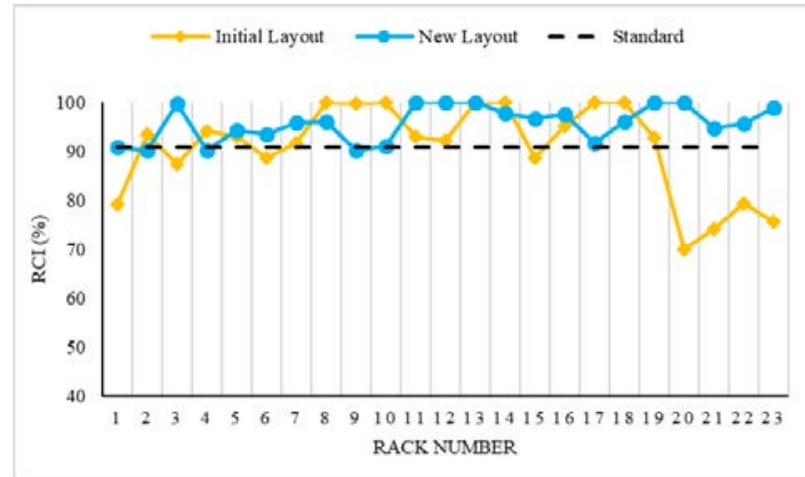

Fig. 18: Comparison of the Rack Cooling Index from initial room layout with new room layout based on the simulation

Figure 19 shows that the average line of the old layout is above the new layout with SHI value of 0.353 , while the average new layout has SHI value of 0.306 . This indicates a decrease in the heat mixture from the rack into the cold air flow from the PAC due to the division of the hot zone and cold zone.

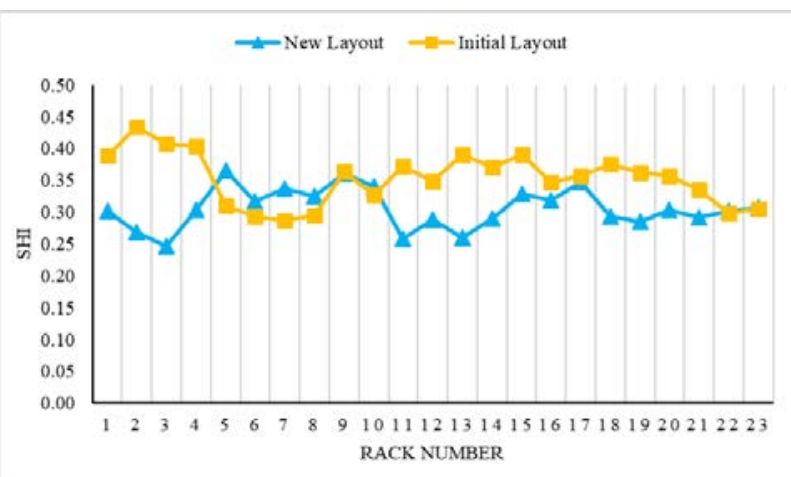

Fig. 19: Comparison of the supply heating index from initial room layout with new room layout based on the simulation

\section{Conclusion}

The research results of CFD simulation in the data center room can be concluded as below:

- Simulation can be carried out where an overview of the distribution of air flow velocity, the distribution of air temperature in the room, and the contour of the rack surface temperature are generated.

- Air flow around the rack can be said to be quite low as shown in the simulation results of $0.4 \mathrm{~m} / \mathrm{s}$. while the air near the PAC area shows a better air velocity, $2 \mathrm{~m} / \mathrm{s}$.

- $\quad$ Air temperature when leaving rack reaches $27^{\circ} \mathrm{C}$, the total temperature in the room reaches $23^{\circ} \mathrm{C}$, while the air temperature entering the PAC reaches $23^{\circ} \mathrm{C}$.

- $\quad$ RCI values in the initial data center layout have 6 main racks of 23 racks which are below the acceptable standard (below $91 \%$ ) with an average value of $90.83 \%$.

- $\quad$ The average SHI value on the main rack is 0.353 .

- The RHI on each rack has fully complied with the recommendation standards of ASHRAE where a maximum of $60 \%$ is recommended.

- New layouts can be made and simulated by considering the existence of a temperature zone, namely the hot aisle and cold aisle as an increase in the effectiveness of rack cooling.

- After rearranging the layouts, the RCI value gets better with an average value of $95.75 \%$.

- $\quad$ The layout recommendation also found that the SHI value is lower, i.e. 0.306, meaning that less heat is mixed with cold air from the PAC.

\section{Acknowledgments}

This research was funded by "Hibah Penelitian Dasar Unggulan Perguruan Tinggi (PDUPT)” of the Ministry of Research, Technology, and Higher Education, the Republic of Indonesia to Nasruddin, according to Surat Keputusan Number 6/E/KPT/2019 date: February $19^{\text {th }}$, 2019 and Perjanjian/Contract Number 1/E1/KP.PTNBH/2019 and 234/PKS/R/UI/2019 date: March $12^{\text {th }}$, $2019 \quad$ also NKB-1652/UN2.R3.1/HKP.05.00/2019 date: March 29th, 2019.

\section{Nomenclature}

IT : Information technology

DCR : Data center room

RCI : Rack Cooling Index

SHI : Supply Heating Index

ASHRAE : American Society of Heating, Refrigerating and Air-Conditioning Engineers

CRAC : Computer room air conditioning

PCM : Phase Change Material

AC : Air Conditioning

CFD : Computational Fluid Dynamics

RHI : Rack Cooling Index

$\mathrm{T}_{\mathrm{x}} \quad$ : Temperature of the air entering the rack, ${ }^{\circ} \mathrm{C}$

$\mathrm{T}_{\text {max-rec }}$ : The maximum recommended 
temperature, ${ }^{\circ} \mathrm{C}$

$\mathrm{T}_{\max \text {-all }} \quad$ : The maximum allowable temperature, ${ }^{\circ} \mathrm{C}$

SQ : The enthalpy change/rise due to the heat mixed into the cold air from the AC supply.

Q : The total enthalpy change that occurs in the rack

CAD : Computer-Aided Design

PAC : Precision Air Conditioning

RH : Relative Humidity

\section{References}

1) K.T. Zingre, X. Yang, and M.P. Wan, "Performance analysis of cool roof, green roof and thermal insulation on a concrete flat roof in tropical climate," Evergreen, (2015).

2) ASHRAE Technical Committee 9.9, "Thermal Guidelines for Data Processing Environments," 2011.

3) C. Peng, L. Wang, and X. Zhang, "DeST-based dynamic simulation and energy efficiency retrofit analysis of commercial buildings in the hot summer/cold winter zone of china: a case in nanjing," Energy Build.,

(2014). doi:10.1016/j.enbuild.2014.04.023.

4) E. Oró, A. Garcia, and J. Salom, "Experimental and numerical analysis of the air management in a data centre in spain,” Energy Build., (2016). doi:10.1016/j.enbuild.2016.01.037.

5) T. Dreibholz, M. Becke, and H. Adhari, "Report to congress on server and data center energy efficiency public law 109-431,” Tdr.Wiwi.Uni-Due.De, (2007).

6) A. Habibi Khalaj, and S.K. Halgamuge, "A review on efficient thermal management of air- and liquid-cooled data centers: from chip to the cooling system,” Appl. Energy, (2017). doi:10.1016/j.apenergy.2017.08.037.

7) K. Choo, R.M. Galante, and M.M. Ohadi, "Energy consumption analysis of a medium-size primary data center in an academic campus,” Energy Build., (2014). doi:10.1016/j.enbuild.2014.02.042.

8) A.G. Alam, Nasruddin, A. Tirta, and C.K. Priambada, "Building beneficial roof insulation in vertical housing : physical and economical selection method," Evergreen, (2019). doi:10.5109/2321006.

9) J. Ni, and X. Bai, "A review of air conditioning energy performance in data centers,” Renew. Sustain. Energy Rev., (2017). doi:10.1016/j.rser.2016.09.050.

10) K. Ebrahimi, G.F. Jones, and A.S. Fleischer, "A review of data center cooling technology, operating conditions and the corresponding low-grade waste heat recovery opportunities," Renew. Sustain. Energy Rev., (2014). doi:10.1016/j.rser.2013.12.007.
11) L.A. Barroso, J. Clidaras, and U. Hölzle, "The datacenter as a computer: an introduction to the design of warehouse-scale machines, second edition," Synth. Lect. Comput. Archit., (2013). doi:10.2200/S00516ED2V01Y201306CAC024.

12) J. Koomey, "Growth in data center electricity use 2005 to 2010,” Anal. Press., (2011). doi:10.1088/1748-9326/3/3/034008.

13) H. Zhang, S. Shao, H. Xu, H. Zou, and C. Tian, "Free cooling of data centers: a review," Renew. Sustain. Energy Rev., (2014). doi:10.1016/j.rser.2014.04.017.

14) P. Pillai, and K.G. Shin, "Real-time dynamic voltage scaling for low-power embedded operating systems," Oper. Syst. Rev., (2001). doi:10.1145/502059.502044.

15) H. Rong, H. Zhang, S. Xiao, C. Li, and C. Hu, "Optimizing energy consumption for data centers," Renew. Sustain. Energy Rev., (2016). doi:10.1016/j.rser.2015.12.283.

16) T. Lu, X. Lü, M. Remes, and M. Viljanen, "Investigation of air management and energy performance in a data center in finland: case study," Energy Build., doi:10.1016/j.enbuild.2011.08.034.

(2011).

17) J. Siriwardana, S. Jayasekara, and S.K. Halgamuge, "Potential of air-side economizers for data center cooling: a case study for key australian cities,” Appl. Energy, (2013). doi:10.1016/j.apenergy.2012.10.046.

18) N. Rasmussen, "Air distribution architecture options for mission critical facilities,” Elektron, (2005).

19) M. Jonas, R.R. Gilbert, J. Ferguson, G. Varsamopoulos, and S.K.S. Gupta, "A transient model for data center thermal prediction,” in: 2012 Int. Green Comput. Conf. IGCC 2012, 2012. doi:10.1109/IGCC.2012.6322262.

20) A.H. Beitelmal, and C.D. Patel, "Thermo-fluids provisioning of a high performance high density data center," Distrib. Parallel Databases, (2007). doi:10.1007/s10619-005-0413-0.

21) R.R. Schmidt, and M. Iyengar, "Comparison between underfloor supply and overhead supply ventilation designs for data center high-density clusters,” in: ASHRAE Trans., 2007.

22) M.K. Herrlin, "Rack cooling effectiveness in data centers and telecom central offices: The Rack Cooling Index (RCI),” in: ASHRAE Trans., 2005.

23) W.K. Yinn, H.M. Kamar, and N. Kamsah, "Effects of surgical staff turning motion on airflow distribution inside a hospital operating room," Evergreen, (2019).

24) J. Cho, T. Lim, and B.S. Kim, "Measurements and predictions of the air distribution systems in high compute density (internet) data centers,” Energy Build., (2009). doi:10.1016/j.enbuild.2009.05.017.

25) R.K. Sharma, C.E. Bash, and C.D. Patel, "Dimensionless parameters for evaluation of thermal 
design and performance of large-scale data centers," in: 8th AIAA/ASME Jt. Thermophys. Heat Transf.

Conf., 2002. 